\title{
Review
}

\section{The Changing Landscape of Parkinson Epidemiologic Research}

\author{
Honglei Chen* \\ Department of Epidemiology and Biostatistics, College of Human Medicine, Michigan State University, \\ East Lansing, MI, USA
}

Accepted 20 October 2017

\begin{abstract}
Despite recent successes in understanding the genetics of Parkinson's disease (PD), the causes of late-onset sporadic PD remain elusive. Many of the epidemiologic findings on PD etiology have been challenged by alternative explanations such as reverse causation. This is mainly because PD often takes decades to develop before it can be diagnosed late in life. Convincing evidence shows that this prodromal stage of PD is characterized by various prodromal symptoms such as olfactory impairment and rapid-eye-movement sleep behavior disorder (RBD). As they likely reflect PD pathogenesis years, if not decades, before nigrostriatal involvement, research on these symptoms may represent an unprecedented opportunity to dissect the etiology of PD. Using PD prodromal symptoms as intermediate phenotypes, we may be able to identify factors that contribute to the development of these symptoms and factors that modify their progression to clinical PD. Further, this line of research will also enable examinations of novel etiological hypotheses of PD development such as the microbiome and prion hypotheses. In this article, the author used olfactory impairment and RBD as examples to illustrate the promises and challenges of epidemiologic research on prodromal symptoms to understand PD etiology.
\end{abstract}

Keywords: Epidemiology, Parkinson's disease, olfaction disorders, REM sleep behavior disorder, risk factors, smoking

\section{INTRODUCTION}

The past two decades have seen evolutionary advances in understanding the genetics of complex diseases, including Parkinson's disease (PD). With the most recent report [1], approximately $40 \mathrm{PD}$ susceptibility loci have been identified from seminal genome-wide association studies with tens of thousands of PD cases and controls. Although these genetic findings have significantly improved our understanding of PD etiology with novel mechanistic insights [2], their overall contribution to late-onset sporadic PD remains uncertain. Environmental factors and gene-environment interactions may also play

\footnotetext{
*Correspondence to: Honglei Chen, MD, PhD, Department of Epidemiology and Biostatistics, College of Human Medicine, Michigan State University, 909 Fee Rd, East Lansing, MI 48824, USA. Tel.: +1 517884 3990; E-mail: hchen@epi.msu.edu.
}

important role in PD etiology [3]; however, this line of research has been hampered by the many challenges of studying PD etiology in epidemiologic studies.

\section{CONTROVERSIES ABOUT PD EPIDEMIOLOGIC FINDINGS: CIGARETTE SMOKING AS AN EXAMPLE}

PD is a relatively rare disease that predominantly affects adults 65 years or older. However, the disease may take decades to develop before a clinical diagnosis is even possible late in life. Particularly with the emergence of large cohorts for PD research in the past two decades, epidemiologic studies have identified or confirmed a range of factors in association with PD risk [3]. Although a detailed discussion of these findings is beyond the scope of this paper, I summarized major PD "etiological" findings from 
epidemiologic studies in Table 1. Most of these findings are reasonably consistent across studies. Further, these factors are modifiable, and if proven causal, they will have profound implications in PD prevention. There are, however, debates about the causality for most of these associations. I will use cigarette smoking as an example to illustrate the main controversies.

A strong inverse association with cigarette smoking is the most robust epidemiologic finding for PD $[4,5]$. This observation started with case-control studies about fifty years ago [6] and was later confirmed in numerous epidemiologic studies, including recent large prospective cohorts $[4,7]$. The risk reduction was substantial with about $50 \%$ lower risk among active smokers as compared to never smokers [8]. Most studies also demonstrated strong dose-response relationships with quantitative matrixes of smoking, including duration, intensity, pack-years, and years since last smoking. Recent analyses further suggest that the duration of smoking, not intensity, is underlying the association of smoking with PD $[4,5,7]$. In addition to cigarette smoking, several studies also evaluated passive smoking [9-12] or smokeless tobacco use (e.g., chewing and snus use) [13-15] in relation to PD. Although such data are still preliminary, evidence supports inverse associations. Interestingly, one study [16] reported higher intake of nicotine from foods (e.g. eggplants and potatoes) was also modestly associated with a lower risk of PD. As dietary contribution to nicotine is almost negligible as compared to that from cigarettes, this observation, together with data on smoking duration, suggests that if nicotine is indeed neuroprotective against PD, its biological effect may be saturated at a very low dose but require a long-term exposure.

While the epidemiologic evidence is overwhelming, debates on the causality between smoking and PD has never abated [17]. There are two major alternative explanations: 1) the personality hypothesis that individuals predisposed to PD tend to have a risk-averse personality and thus are less like to start smoking in early life; and 2) the reverse causation hypothesis that smokers are more likely to quit smoking during prodromal PD for various reasons (e.g., nonmotor symptoms). Although there is important evidence against alternative explanations [18-21], it is sparse and modest. Given the presumed decadeslong and complex prodromal development of PD, one cannot exclude alternative explanations.

In addition to smoking, recent large epidemiologic analyses have also identified or confirmed inverse associations of $\mathrm{PD}$ with several other lifestyle factors [3], including coffee consumption, tea drinking, physical activities, plasma urate, plasma cholesterols, use of ibuprofen, statins, and L-type calcium channel blockers, as well as positive associations with head injury, pesticide use, and high intake of dairy or milk (Table 1). For each, there is evidence from multiple studies [3]. However, compared with smoking and PD, these associations are weaker in strength and less consistent across studies. For most of these findings, the same arguments for alternative explanations apply. For example, several cohort studies have showed an inverse association of physical activity with PD, especially vigorous exercise $[22,23]$. While this association is biologically plausible, one may reasonably argue that people in prodromal PD may have lower physical capacity and thus are less physically active years prior to PD diagnosis (i.e., reverse causation). Further, compared to habitual smoking, other lifestyle and environmental exposures are often much more difficult to measure, adding complexity to causal inference.

\section{CHALLENGES TO STUDY PD RISK FACTORS IN EPIDEMIOLOGY}

Many of these controversies stem from the fact that PD prodromal development takes decades and involves multiple organs. The Braak hypothesis, although somewhat controversial, posits PD pathogenesis starts in the olfactory bulb, lower brain stem, or even periphery nerves before spreading to midbrain $[24,25]$. This prodromal stage may take two decades or longer [25]. In support of this, clinical and epidemiologic studies have documented various nonmotor symptoms, such as olfactory impairment, sleep disturbances, and constipation years, if not decades, prior to PD clinical diagnosis. It is conceivable that, during this prolonged process, many etiological factors may come into play to initiate PD pathogenesis, modify its progression, or both. To date, few efforts have been made to document roles of these factors [26, 27]. Further, some of these factors may change over time as a result of PD prodromal development. For example, anosmia or sleep disturbances in prodromal PD may lead to reduced coffee drinking, and fatigue, pain, and subtle motor symptoms may lead to less physical activity. Unfortunately, available epidemiologic studies have largely ignored this complex and dynamic prodromal stage of PD, and have taken a black-box approach by examining a snapshot of risk factors at a single time 
Table 1

Summary of selected epidemiologic findings on potential modifiable "protective" or "risk" factors for PD

\begin{tabular}{|c|c|c|c|c|}
\hline & Study design & Main findings & $\begin{array}{l}\text { Major alternative } \\
\text { explanations }\end{array}$ & $\begin{array}{l}\text { Epidemiologic evidence } \\
\text { against alternative } \\
\text { explanations }\end{array}$ \\
\hline \multicolumn{5}{|c|}{ Potential modifiable "protective" factors } \\
\hline Smoking & $\begin{array}{l}\text { Cohort }[4,7] \& \\
\text { case-control [5] }\end{array}$ & $\begin{array}{l}\text { Strong inverse } \\
\text { association, very } \\
\text { consistent }\end{array}$ & $\begin{array}{l}\text { Reverse causation / } \\
\text { personality }\end{array}$ & $\begin{array}{l}\text { Moderate with evidence } \\
\text { on passive smoking } \\
\text { [9-12], twin studies } \\
{[18,19],} \\
\text { transgenerational } \\
\text { exposure [20], secular } \\
\text { trend [21] }\end{array}$ \\
\hline Coffee drinking & $\begin{array}{l}\text { Cohort }[80,81] \& \\
\text { case-control [82] }\end{array}$ & $\begin{array}{l}\text { Moderate inverse } \\
\text { association, consistent }\end{array}$ & $\begin{array}{l}\text { Reverse causation / } \\
\text { personality }\end{array}$ & $\begin{array}{l}\text { Weak, specificity to } \\
\text { caffeinated coffee and } \\
\text { caffeine from other } \\
\text { sources (e.g., tea } \\
\text { drinking) }[81,83,84]\end{array}$ \\
\hline Exercise & Mostly cohorts $[22,23]$ & $\begin{array}{l}\text { Moderate inverse } \\
\text { association, consistent }\end{array}$ & Reverse causation & Weak or none \\
\hline Plasma urate & $\begin{array}{l}\text { Mostly cohort [85] \& } \\
\text { nested case-control [86] }\end{array}$ & $\begin{array}{l}\text { Moderate inverse } \\
\text { association, consistent }\end{array}$ & Reverse causation & $\begin{array}{l}\text { Weak, Mendelian } \\
\text { randomization analysis } \\
\text { on PD progression [87] }\end{array}$ \\
\hline Total/LDL cholesterols & $\begin{array}{l}\text { Cohort [88] \& } \\
\text { case-control [89] }\end{array}$ & $\begin{array}{l}\text { Moderate inverse } \\
\text { association, mostly } \\
\text { consistent }\end{array}$ & $\begin{array}{l}\text { Reverse causation, } \\
\text { confounding }\end{array}$ & Weak or none \\
\hline NASIDs / Ibuprofen & $\begin{array}{l}\text { Cohort [90] \& } \\
\text { case-control [91] }\end{array}$ & $\begin{array}{l}\text { Moderate inverse } \\
\text { association, mostly } \\
\text { consistent }\end{array}$ & Confounding & $\begin{array}{l}\text { Specificity to ibuprofen } \\
{[90,92]}\end{array}$ \\
\hline Statins & $\begin{array}{l}\text { Cohort }[88,93] \& \\
\text { case-control [94, 95] }\end{array}$ & $\begin{array}{l}\text { Moderate inverse } \\
\text { association, } \\
\text { inconsistent }\end{array}$ & $\begin{array}{l}\text { Confounding, especially } \\
\text { by indication (i.e., high } \\
\text { cholesterol) }\end{array}$ & $\begin{array}{l}\text { Little, inconsistent } \\
\text { evidence for lipophilic } \\
\text { statins }[95,96]\end{array}$ \\
\hline Calcium channel blocker & $\begin{array}{l}\text { Cohort [97] \& } \\
\text { case-control [98] }\end{array}$ & Mixed and inconsistent & Confounding & Weak or none \\
\hline \multicolumn{5}{|c|}{ Potential modifiable "risk" factors } \\
\hline Pesticides & $\begin{array}{l}\text { Mostly case-control } \\
{[99,100]}\end{array}$ & $\begin{array}{l}\text { Moderate to strong } \\
\text { positive association, } \\
\text { consistent }\end{array}$ & Recall bias & $\begin{array}{l}\text { One cohort study [101], } \\
\text { and evidence on } \\
\text { specific pesticides [99, } \\
100]\end{array}$ \\
\hline Head injury & $\begin{array}{l}\text { Mostly case-control } \\
{[75,102]}\end{array}$ & $\begin{array}{l}\text { Moderate positive } \\
\text { association, mostly } \\
\text { consistent }\end{array}$ & $\begin{array}{l}\text { Reverse causation / recall } \\
\text { bias }\end{array}$ & $\begin{array}{l}\text { Modest suggestive } \\
\text { evidence on head injury } \\
\text { in early life }[75,76] \text {; } \\
\text { use of negative controls } \\
\text { [103] }\end{array}$ \\
\hline Dairy products & Mostly cohort $[104,105]$ & $\begin{array}{l}\text { Moderate positive } \\
\text { association, mostly } \\
\text { consistent }\end{array}$ & Confounding & $\begin{array}{l}\text { Modest suggestive } \\
\text { evidence on specific } \\
\text { types of dairy } \\
{[104-106]}\end{array}$ \\
\hline
\end{tabular}

Only listed representative publications; I did not automatically consider supportive data from prospective studies as evidence against reverse causation given the long prodromal period of PD.

point in relation to PD diagnosed years or decades later (Fig. 1).

\section{PRODROMAL SYMPTOMS: A MAJOR OPPORTUNITY TO DISSECT PD ETIOLOGY}

Although challenging, prodromal PD presents a major opportunity to improve our understanding of disease etiology [28] (Fig. 2). Using prodromal symptoms as intermediate phenotypes, scientists will have the first serious opportunity to unveil how PD starts and develops in its early stages. Further, investigation on progression from prodromal symptoms to PD may eventually lead to prevention of the disease. Second, research on prodromal PD will enable scientists to examine novel etiological hypotheses. Examples include the two-hits hypothesis [29], the microbiome hypothesis [30], and the prion-like 


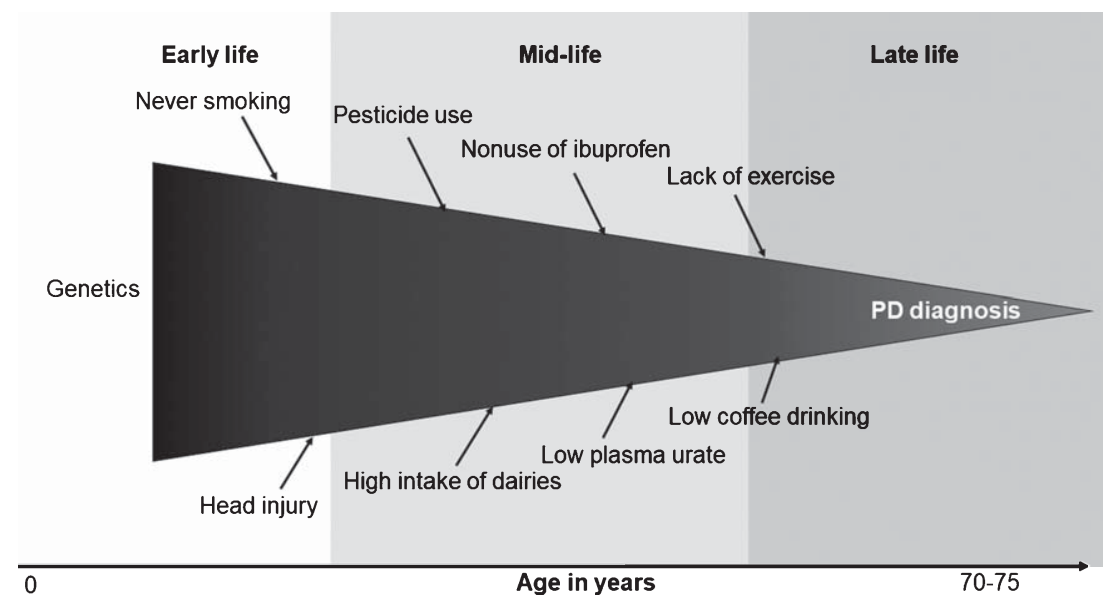

Fig. 1. The black-box approach to Parkinson's disease (PD) etiological research.

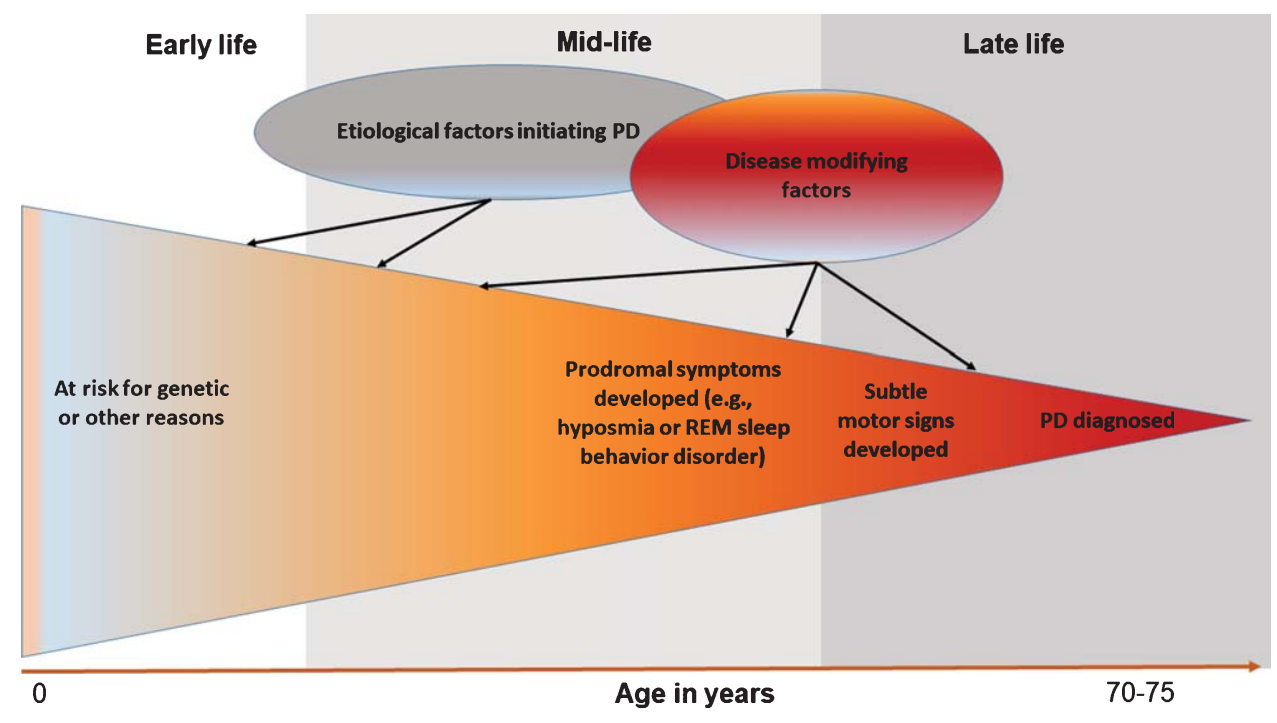

Fig. 2. Research on prodromal symptoms of Parkinson's disease (PD) helps dissect disease etiology.

hypothesis about PD development [31]. As there are excellent reviews on these novel etiological hypotheses [29-31], this review focuses on how research on prodromal symptoms may lead to a better understanding of factors that contribute to various stages of PD development. I will illustrate these ideas using olfactory impairment and rapid-eye-movement sleep behavior disorder (RBD) as examples, and will discuss the complexities in their implementation. I choose to focus on these two symptoms because olfactory impairment is the most sensitive and RBD the most specific prodromal symptom of PD, and because both symptoms are important parts of the international Movement Disorder Society newly proposed research criteria for prodromal PD [32].
Olfactory impairment is the most prevalent nonmotor symptom among PD patients. Our recent meta-analyses showed that $76 \%$ of PD patients had olfactory impairment as compared to $19 \%$ of controls [33]. Further, case-control analyses showed that, at the population level, olfactory impairment is the most predictive nonmotor symptom that could efficiently differentiate PD cases from controls [34]. The Braak hypothesis further suggests olfactory impairment is one of the earliest symptoms of PD. However empirical data from population-based prospective studies are limited [33] and the temporal relationship has been poorly understood. For example, in the Honolulu Asia Aging Study (HAAS) [35], a poor sense of smell predicted PD risk within four years but not 
beyond. The Prospective Evaluation of Risk factors for Idiopathic Parkinson's Syndrome (PRIPS) study only reported data up to 5 years of follow-up [36]. We recently analyzed data from the Health $\mathrm{ABC}$ study with a median of 10 years of follow-up [37]. Compared to participants with good olfaction, those with poor olfaction were about 5-times more likely to develop PD, and the risk persisted beyond five years of follow-up. Given the one-time only assessment of olfaction in these studies, age at evaluation ( $\sim 79$ in HAAS and $\sim 76$ in Health ABC), and length of follow-up, current data likely have underestimated the number of years of olfactory impairment leading to PD.

The Parkinson's At-Risk Study (PARS) further investigated factors that contributed to the conversion from olfactory impairment to PD [38]. The study followed 152 hyposmia patients for four years and 19 converted to PD as compared to none of the 26 individuals with normal olfaction. Of those with hyposmia, dopamine transporter neuroimaging deficit greatly predicted conversion rate to PD (relative risk $(\mathrm{RR})=17.5,95 \%$ confidence interval $(\mathrm{CI})$ : 7.0-43.4). In addition, age $>65$ years $(\mathrm{RR}=2.5,95 \%$ CI: $1.0-6.0)$ and constipation $(\mathrm{RR}=2.7,95 \% \mathrm{CI}$ : 1.2-6.2) were also associated with higher conversion rate. Comparable RRs were also reported for RBD $(\mathrm{RR}=2.8)$ and depression $(\mathrm{RR}=2.4)$, but likely due to the small numbers, the differences were not statistically significant. Further, convertors were more likely to be men ( $74 \%$ vs. $53 \%)$, but no statistical testing was reported. The study did not examine lifestyle or environmental factors such as smoking, coffee drinking, head injury, or pesticide use.

Causes for olfactory impairment are also poorly understood. Knowledge comes mainly from clinical studies of acquired causes such as sinonasal diseases and head trauma. Except for age and male sex [39], impacts from other demographics, lifestyle, and environmental exposures on olfaction are largely unknown. Table 2 summarizes current literature on olfactory impairment for factors that have shown a robust association with PD. With few exceptions $[40,41]$, the data are exclusively from cross-sectional analyses, and only smoking has been evaluated in more than a few studies. The results on smoking are not consistent, mostly positive [39, 42-45] or null [46-49], but inverse associations were also reported [50,51]. A recent meta-analysis [52] showed that while past smoking was not related to olfactory impairment (odds ratio $(\mathrm{OR})=1.05,95 \% \mathrm{CI}$ : 0.91-1.21), current smoking was associated with a higher prevalence $(\mathrm{OR}=1.59,95 \% \mathrm{CI}: 1.37-1.85)$. This meta-analysis, however, did not include the most recent and the largest analysis to date $(n=8,557)$ where a modest non-statistically significant inverse association with current smoking was suggested $(\mathrm{OR}=0.79,95 \%$ CI: 0.58-1.06) [49].

Three studies have further examined smoking and olfaction among PD cases [53-55], aiming to explore whether smoking protects phenotypical conversion from olfactory impairment to PD. However, analyses of smoking and olfaction conditioned on PD will create a collider issue in epidemiologic causal inference and thus might have generated spurious findings [56]. Taken together, the overall epidemiological data do not support a major role of cigarette smoking in olfactory impairment and data of phenotypical conversion is lacking.

$\mathrm{RBD}$ is another research focus of prodromal PD. Approximately $40 \%$ of PD patients have RBD and about a half may have developed prior to PD diagnosis [33]. Unlike olfactory impairment and other prodromal symptoms, clinically diagnosed RBD with polysomnography (PSG) confirmation is very specific to PD or related synucleinopathy [57, 58]. Clinical studies suggest up to $80 \%$ of PSG-confirmed RBD patients eventually develop PD, dementia with Lewy bodies, or multiple system atrophy [57, 58]. The exact temporal relationship of RBD to PD is yet to be defined, but the leading time is likely beyond a decade. In an extreme example, evidence of RBD was found up to five decades before neurodegenerative diagnoses [59]. Although this clinical link has been solidly established, the contribution of RBD to PD in the general population is yet to be defined. Clinical diagnosis of RBD requires PSG evidence, which is often infeasible in large population-based studies. Several RBD screening questionnaires have been developed with high sensitivity and specificity in clinic-based validation studies [60-63]. However, when applied in the general population, they often gave a prevalence of 3-7\% for the so-called "probable" RBD (pRBD) [64-67], much higher than the expected $\sim 1 \%$ for RBD $[68,69]$. This may be largely attributed to false positives from obstructive sleep apnea or RBD mimics; on the other hand, it is also possible that $\mathrm{RBD}$ is underdiagnosed in the general population as patients with violent behaviors and physical injuries may be much more likely to end up in sleep clinics than those with mild symptoms [69].

Given the connection of PSG-confirmed RBD to clinical synucleinopathy, several studies have investigated factors that may modify RBD pheno- 
Table 2

Current literature on olfactory impairment or RBD for selected well-established associations for PD

\begin{tabular}{|c|c|c|c|c|}
\hline & \multicolumn{2}{|c|}{ Olfactory impairment } & \multicolumn{2}{|c|}{ RBD } \\
\hline & Risk or prevalence & Conversion to PD & Risk or prevalence & $\begin{array}{l}\text { Conversion to PD } \\
\text { or another } \\
\text { synucleinopathy }\end{array}$ \\
\hline \multicolumn{5}{|l|}{ Demographics } \\
\hline Age & $\begin{array}{l}\text { Age dependency similar } \\
\text { to } \mathrm{PD}[39,41,49,51]\end{array}$ & Older age [38] & $\begin{array}{l}\text { Modest [27] or no age } \\
\text { effect }[64,67]\end{array}$ & Older age $[26,107]$ \\
\hline Male sex & $\begin{array}{l}\text { Modest male to female } \\
\text { ratio similar to PD [39, } \\
41,49]\end{array}$ & $\begin{array}{l}\text { Proportionally more men } \\
\text { converted [38], but } \\
\text { statistics not reported. }\end{array}$ & $\begin{array}{l}\text { High male dominance of } \\
\text { RBD in clinical } \\
\text { samples }[58,108-111] \\
\text { moderate sex ratio for } \\
\text { pRBD in } \\
\text { population-based } \\
\text { studies }[64,67] .\end{array}$ & Null $[26,107]$ \\
\hline \multicolumn{5}{|c|}{ Potential modifiable "protective" factors } \\
\hline Smoking & $\begin{array}{l}\text { Mostly positive }[39,42, \\
45,112-114] \text { or null } \\
{[40,44,47,49,52,} \\
115-117] ; \text { inverse also } \\
\text { reported }[50,51]\end{array}$ & No data & $\begin{array}{l}\text { Positive [27] and null [64, } \\
\text { 67] }\end{array}$ & Null $[26,107]$ \\
\hline Coffee drinking & $\begin{array}{l}\text { Rarely examined, inverse } \\
{[116]}\end{array}$ & No data & Null $[27,64,67]$ & Null [26] \\
\hline Exercise & $\begin{array}{l}\text { Inverse }[41,51] \text { or null } \\
\quad[114,116]\end{array}$ & No data & Null [64]; inverse [67] & No data \\
\hline \multicolumn{5}{|c|}{ Potential modifiable "risk" factors } \\
\hline Pesticides & $\begin{array}{l}\text { Rarely examined, case } \\
\text { report [118], suggestive } \\
\text { positive [119] or null } \\
\text { [116] }\end{array}$ & No data & $\begin{array}{l}\text { Positive [27]; } \\
\text { Non-significantly } \\
\text { positive [64] }\end{array}$ & Inverse [26] \\
\hline Head injury & $\begin{array}{l}\text { Evidence largely on } \\
\text { post-traumatic olfaction } \\
\text { impairment [120]; } \\
\text { limited and inconsistent } \\
\text { data on age-related } \\
\text { olfactory impairment, } \\
\text { positive [114] or null } \\
{[49,51]}\end{array}$ & No data & Positive $[27,64,67]$ & Null [26] \\
\hline
\end{tabular}

typical conversion and have found influences from olfactory impairment and other nonmotor symptoms $[57,70]$. One study further examined potential roles of lifestyle and environmental exposures [26] on RBD phenotypical conversion. In this 4-year follow-up of 305 RBD patients, age is associated with conversion, but neither sex, smoking, caffeine intake, head injury, obesity, nor alcohol drinking was associated with the conversion rate. Ironically, insecticide use, either occupational or non-occupational, was associated with a substantially lower probability of phenotypical conversion [26]. This study also reported that higher plasma cholesterol level was associated with a lower likelihood of conversion, which is consistently with epidemiologic findings on PD [26].

To our best knowledge, only three epidemiologic studies have examined factors that affect the risk or prevalence of RBD, including a multicenter case-control study with PSG-confirmed RBD [27] and two cross-sectional analyses in China with pRBD from screening [64, 67]. Unlike olfactory impairment, age does not appear to be a strong risk factor for RBD [27, 64, 67]. Smoking was positively associated with RBD in the case-control study [27], but not in the two cross-sectional analyses [64, 67]. Coffee drinking or caffeine intake was not related to RBD in all three studies [27, 64, 67]. Interestingly, these data consistently support positive associations of RBD with head injury and pesticide use [27, 64, 67], consistent with findings on PD. In addition to these well-known risk factors for PD, these studies also consistently identified an association of RBD with lower education [27, 64, 67], a proxy of lower socio-economic status and possibly more hazardous environmental exposures. 
These findings on olfactory impairment or RBD are very preliminary. Nevertheless, they suggest that cigarette smoking is not inversely associated with the presence of either symptom. These preliminary data, however, do not necessarily rule out the possibility that smoking reduces PD risk. First, smoking may have differential roles in the development as compared to progression of these symptoms, and the latter has not been thoroughly examined. It is possible that smoking may selectively protect nigrostriatal dopaminergic neurons at later stage of prodromal PD, rather than earlier Lewy pathology accumulation at relevant extranigral structures [26]. Second, 15-25\% of older adults suffer from olfactory impairment $[39,49]$, which might be caused by a range of reasons. It is likely that only a minority of olfactory impairment have a root in neurodegeneration, and of these only a fraction will eventually progress to $\mathrm{PD}$. Consistent with this possibility, a poor sense of smell is associated with incidental Lewy body disease among individuals who died without any clinical symptoms $[71,72]$. In the case for RBD, as only about $20 \%$ of PD patients develop RBD prior to PD clinical diagnosis [33], we could not exclude differential relationships between smoking and PD subtypes. In support of this argument, a recent study found that PD patients with RBD were more likely to be smokers as compared with patients without RBD [73]. Future well-planned prospective research on prodromal symptoms will be needed to clarify the role of smoking in prodromal PD.

Although data are not entirely consistent, a recent meta-analysis showed that a history of head trauma was associated with $\sim 60 \%$ higher risk of PD [74]. Two studies further showed that head injury in early life was especially associated with a higher risk of PD [75, 76]. The recent data on poor olfaction and RBD [27, 64, 67] further add to the evidence that head injury plays a role in early stages of PD development.

The apparently contradictory data on pesticides and RBD prevalence versus phenotypical conversion are also interesting. Two studies showed that occupational pesticide exposure was associated with having RBD [27, 64], whereas the 4-year follow-up study found that pesticide exposure was associated with lower phenotypical conversion [26]. While these data are preliminary and chance could not be excluded, it is possible that pesticides may be associated with a higher risk of RBD but a slower progression to clinical outcomes [26]. This differential relationship awaits confirmation and clarification.

\section{CHALLENGES AND FUTURE RESEARCH}

Although a prolonged prodromal PD development offers new and exciting opportunities to dissect the etiology and natural history of PD, such research is still in its infancy. Many challenges exist. From an epidemiologic perspective, the biggest obstacle is the lack of specificity of these symptoms to clinical PD and possibly to its underlying pathology. With the exception of PSG-confirmed RBD, other prodromal symptoms are fairly common in the general population and can be caused by many reasons unrelated to neurodegeneration. For example, the most common causes for olfactory impairment are chronic rhinosinusitis, upper respiratory tract infections, and head injury. Current epidemiologic studies on PD often failed to differentiate various causes among older adults. Further, as discussed earlier, it is likely that, even among older adults with neurodegenerationrelated olfactory impairment, only a small proportion will progress to a full blown clinical PD in their lifetime. Simultaneous consideration of multiple prodromal symptoms may increase the specificity, but this approach will inadvertently decrease sensitivity and data generalizability. Second, prodromal PD development may take two decades or longer, and we know little about the temporal relationships of nonmotor symptoms in prodromal PD. Most available epidemiologic studies assessed nonmotor symptoms only once late in life. They are therefore not very informative about key research questions such as when these symptoms start and how they progress or fluctuate in prodromal PD. The prodromal PD development is likely a highly dynamic process that requires repeated symptomatic assessments and monitoring.

An ideal epidemiologic study on PD etiology should encompass the full spectrum of PD prodromal development with the following characteristics: a sufficiently large population-based study sample free of major prodromal symptoms of neurodegeneration at enrollment, detailed assessments of risk factors, and decades of follow-up with updated exposure assessments and monitoring of nonmotor and motor symptoms as well as disease outcomes. Such a study is however infeasible and cost prohibitive. Alternative approaches have been taken, mostly focusing on at-risk populations to study phenotypical conversion. For example, the PARS Study targets individuals with a positive family history of PD, who were first screened with a sense of smell test, and then followed individuals who had olfactory impairment 
with repeated dopamine transporter imaging and clinical assessments [38]. On the other hand, the TREND (Tübinger evaluation of Risk factors for the Early detection of NeuroDegeneration) study follows a risk-enriched population with symptoms of hyposmia, RBD, and depression [77]. There is also the aforementioned exemplary international collaboration to investigate phenotypical conversion from clinically diagnosed RBD to neurodegenerative diseases [26]. While these studies are instrumental to understanding symptom progression and phenotypical conversion, they had limited data on risk factors and do not address how these symptoms occur in the first place. There are ongoing efforts to adapt large prospective epidemiologic studies initially designed to study cancer and cardiovascular diseases for research on prodromal PD. Examples include the Health Professionals Follow-up Study and the Nurses' Health Study [78], the Rotterdam Study [79], the Atherosclerosis Risk In Communities Study [49], and the Health ABC Study [49]. These cohorts are typically large and populationbased, recruited participants in their mid-adulthood, have collected enormous risk factor data (e.g., diet, lifestyle, environment, and genetics), and have followed participants for decades. Further, these cohorts all have parallel research on clinical PD and thus allow for investigations on these symptoms in the context of PD development. We expect these large cohort studies, together with clinical and epidemiologic efforts on phenotypical conversion, will bring answers to fundamental questions about PD etiology and beyond.

\section{ACKNOWLEDGMENTS}

The author is supported by a start-up fund from the Michigan State University (GE100455).

\section{CONFLICT OF INTEREST}

The author has no conflict of interest to report.

\section{REFERENCES}

[1] Chang D, Nalls MA, Hallgrímsdóttir IB, Hunkapiller J, van der Brug M, Cai F, International Parkinson's Disease Genomics Consortium, 23 and Me Research Team, Kerchner GA, Ayalon G, Bingol B, Sheng M, Hinds D, Behrens TW, Singleton AB, Bhangale TR, Graham RR (2017) A meta-analysis of genome-wide association studies identifies 17 new Parkinson's disease risk loci. Nat Genet 49, 1511-1516.
[2] Kumaran R, Cookson MR (2015) Pathways to Parkinsonism redux: Convergent pathobiological mechanisms in genetics of Parkinson's disease. Hum Mol Genet 24, R32-R44.

[3] Ascherio A, Schwarzschild MA (2016) The epidemiology of Parkinson's disease: Risk factors and prevention. Lancet Neurol 15, 1257-1272.

[4] Chen H, Huang X, Guo X, Mailman RB, Park Y, Kamel F, Umbach DM, Xu Q, Hollenbeck A, Schatzkin A, Blair A (2010) Smoking duration, intensity, and risk of Parkinson disease. Neurology 74, 878-884.

[5] Ritz B, Lee PC, Lassen CF, Arah OA (2014) Parkinson disease and smoking revisited: Ease of quitting is an early sign of the disease. Neurology 83, 1396-1402.

[6] Nefzger MD, Quadfasel FA, Karl VC (1968) A retrospective study of smoking in Parkinson's disease. Am J Epidemiol 88, 149-158.

[7] Thacker EL, O'Reilly EJ, Weisskopf MG, Chen H, Schwarzschild MA, McCullough ML, Calle EE, Thun MJ, Ascherio A (2007) Temporal relationship between cigarette smoking and risk of Parkinson disease. Neurology 68, 764-768.

[8] Breckenridge CB, Berry C, Chang ET, Sielken RL Jr, Mandel JS (2016) Association between Parkinson's Disease and Cigarette Smoking, Rural Living, Well-Water Consumption, Farming and Pesticide Use: Systematic Review and Meta-Analysis. PLoS One 11, e151841.

[9] Mellick GD, Gartner CE, Silburn PA, Battistutta D (2006) Passive smoking and Parkinson disease. Neurology 67, 179-180.

[10] Searles Nielsen S, Gallagher LG, Lundin JI, Longstreth WT Jr, Smith-Weller T, Franklin GM, Swanson PD, Checkoway H (2012) Environmental tobacco smoke and Parkinson's disease. Mov Disord 27, 293-296.

[11] Chen H, Ding D, Wang J, Zhao Q, Meng H, Li H, Gao YT, Shu XO, Tanner CM, Hong Z, Yang G (2015) Parkinson's disease research in a prospective cohort in China. Parkinsonism Relat Disord 21, 1200-1204.

[12] Tanaka K, Miyake Y, Fukushima W, Sasaki S, Kiyohara C, Tsuboi Y, Yamada T, Oeda T, Miki T, Kawamura N, Sakae N, Fukuyama H, Hirota Y, Nagai M, Fukuoka Kinki Parkinson's disease Study, Group (2010) Active and passive smoking and risk of Parkinson's disease. Acta Neurol Scand 122, 377-382.

[13] O'Reilly EJ, McCullough ML, Chao A, Henley SJ, Calle EE, Thun MJ, Ascherio A (2005) Smokeless tobacco use and the risk of Parkinson's disease mortality. Mov Disord 20, 1383-1384.

[14] Liu Z, Roosaar A, Axell T, Ye W (2017) Tobacco use, oral health, and risk of Parkinson's disease. Am J Epidemiol 185, 538-545.

[15] Yang F, Pedersen NL, Ye W, Liu Z, Norberg M, Forsgren L, Trolle Lagerros Y, Bellocco R, Alfredsson L, Knutsson A, Jansson JH, Wennberg P, Galanti MR, Lager AC, Araghi M, Lundberg M, Magnusson C, Wirdefeldt K (2016) Moist smokeless tobacco (Snus) use and risk of Parkinson's disease. Int J Epidemiol 46, 872-880.

[16] Nielsen SS, Franklin GM, Longstreth WT, Swanson PD, Checkoway H (2013) Nicotine from edible Solanaceae and risk of Parkinson disease. Ann Neurol 74, 472-477.

[17] Ritz B, Rhodes SL (2010) After half a century of research on smoking and PD, where do we go now? Neurology 74, 870-871.

[18] Tanner CM, Goldman SM, Aston DA, Ottman R, Ellenberg J, Mayeux R, Langston JW (2002) Smok- 
ing and Parkinson's disease in twins. Neurology 58, 581-588.

[19] Wirdefeldt K, Gatz M, Pawitan Y, Pedersen NL (2005) Risk and protective factors for Parkinson's disease: A study in Swedish twins. Ann Neurol 57, 27-33.

[20] O'Reilly EJ, Chen H, Gardener H, Gao X, Schwarzschild MA, Ascherio A (2009) Smoking and Parkinson's disease: Using parental smoking as a proxy to explore causality. Am J Epidemiol 169(6), 678-682.

[21] Morozova N, O'Reilly EJ, Ascherio A (2008) Variations in gender ratios support the connection between smoking and Parkinson's disease. Mov Disord 23, 1414-1419.

[22] Chen H, Zhang SM, Schwarzschild MA, Hernan MA, Ascherio A (2005) Physical activity and the risk of Parkinson disease. Neurology 64, 664-669.

[23] Xu Q, Park Y, Huang X, Hollenbeck A, Blair A, Schatzkin A, Chen H (2010) Physical activities and future risk of Parkinson disease. Neurology 75, 341-348.

[24] Braak H, Bohl JR, Müller CM, Rüb U, de Vos RAI, Tredici KD (2006) Stanley Fahn Lecture 2005: The staging procedure for the inclusion body pathology associated with sporadic Parkinson's disease reconsidered. Mov Disord 21, 2042-2051.

[25] Hawkes CH, Del Tredici K, Braak H (2010) A timeline for Parkinson's disease. Parkinsonism Relat Disord 16, 79-84.

[26] Postuma RB, Iranzo A, Hogl B, Arnulf I, Ferini-Strambi L, Manni R, Miyamoto T, Oertel W, Dauvilliers Y, Ju YE, Puligheddu M, Sonka K, Pelletier A, Santamaria J, Frauscher B, Leu-Semenescu S, Zucconi M, Terzaghi M, Miyamoto M, Unger MM, Carlander B, Fantini ML, Montplaisir JY (2015) Risk factors for neurodegeneration in idiopathic rapid eye movement sleep behavior disorder: A multicenter study. Ann Neurol 77, 830-839.

[27] Postuma RB, Montplaisir JY, Pelletier A, Dauvilliers Y, Oertel W, Iranzo A, Ferini-Strambi L, Arnulf I, Hogl B, Manni R, Miyamoto T, Mayer G, Stiasny-Kolster K, Puligheddu M, Ju Y, Jennum P, Sonka K, Santamaria J, Fantini ML, Zucconi M, Leu-Semenescu S, Frauscher B, Terzaghi M, Miyamoto M, Unger MM, Cochen De Cock V, Wolfson C (2012) Environmental risk factors for REM sleep behavior disorder: A multicenter case-control study. Neurology 79, 428-434.

[28] Chen H, Burton EA, Ross GW, Huang X, Savica R, Abbott RD, Ascherio A, Caviness JN, Gao X, Gray KA, Hong JS, Kamel F, Jennings D, Kirshner A, Lawler C, Liu R, Miller GW, Nussbaum R, Peddada SD, Comstock Rick A, Ritz B, Siderowf AD, Tanner CM, Troster AI, Zhang J (2013) Research on the Premotor Symptoms of Parkinson's Disease: Clinical and Etiological Implications. Environ Health Perspect 121, 1245-1252.

[29] Reichmann H (2011) View point: Etiology in Parkinson's disease. Dual hit or spreading intoxication. J Neurol Sci 310, 9-11.

[30] Felice VD, Quigley EM, Sullivan AM, O'Keeffe GW, O'Mahony SM (2016) Microbiota-gut-brain signalling in Parkinson's disease: Implications for non-motor symptoms. Parkinsonism Relat Disord 27, 1-8.

[31] Stopschinski BE, Diamond MI (2017) The prion model for progression and diversity of neurodegenerative diseases. Lancet Neurol 16, 323-332.

[32] Berg D, Postuma RB, Adler CH, Bloem BR, Chan P, Dubois B, Gasser T, Goetz CG, Halliday G, Joseph L, Lang AE, Liepelt-Scarfone I, Litvan I, Marek K, Obeso J, Oertel W, Olanow CW, Poewe W, Stern M, Deuschl G (2015) MDS research criteria for prodromal Parkinson's disease. Mov Disord 30, 1600-1611.
[33] Chen H, Zhao EJ, Zhang W, Lu Y, Liu R, Huang X, Ciesielski-Jones AJ, Justice MA, Cousins DS, Peddada S (2015) Meta-analyses on prevalence of selected Parkinson's nonmotor symptoms before and after diagnosis. Transl Neurodegener $\mathbf{4}, 1$.

[34] Liu R, Umbach DM, Peddada SD, Xu Z, Troster AI, Huang X, Chen H (2015) Potential sex differences in nonmotor symptoms in early drug-naive Parkinson disease. Neurology 84, 2107-2115.

[35] Ross GW, Petrovitch H, Abbott RD, Tanner CM, Popper J, Masaki K, Launer L, White LR (2008) Association of olfactory dysfunction with risk for future Parkinson's disease. Ann Neurol 63, 167-173.

[36] Berg D, Godau J, Seppi K, Behnke S, Liepelt-Scarfone I, Lerche S, Stockner H, Gaenslen A, Mahlknecht P, Huber H, Srulijes K, Klenk J, Fassbender K, Maetzler W, Poewe W, group tPs (2013) The PRIPS study: Screening battery for subjects at risk for Parkinson's disease. Eur J Neurol 20, 102-108.

[37] Chen H, Shrestha S, Huang X, Jain S, Guo X, Tranah GJ, Garcia ME, Satterfield S, Phillips C, Harris TB, Health ABCS (2017) Olfaction and incident Parkinson disease in US white and black older adults. Neurology 89, 14411447.

[38] Jennings D, Siderowf A, Stern M, Seibyl J, Eberly S, Oakes D, Marek K, Investigators P (2017) Conversion to Parkinson disease in the PARS Hyposmic and Dopamine Transporter-Deficit Prodromal Cohort. JAMA Neurol 74, 933-940.

[39] Murphy C, Schubert CR, Cruickshanks KJ, Klein BE, Klein R, Nondahl DM (2002) Prevalence of olfactory impairment in older adults. JAMA 288, 2307-2312.

[40] Schubert CR, Cruickshanks KJ, Klein BE, Klein R, Nondahl DM (2011) Olfactory impairment in older adults: Five-year incidence and risk factors. Laryngoscope 121, 873-878.

[41] Schubert CR, Cruickshanks KJ, Nondahl DM, Klein BE, Klein R, Fischer ME (2013) Association of exercise with lower long-term risk of olfactory impairment in older adults. JAMA Otolaryngol Head Neck Surg 139, 10611066.

[42] Vennemann MM, Hummel T, Berger K (2008) The association between smoking and smell and taste impairment in the general population. J Neurol 255, 1121-1126.

[43] Karpa MJ, Gopinath B, Rochtchina E, Jie Jin W, Cumming RG, Sue CM, Mitchell P (2010) Prevalence and neurodegenerative or other associations with olfactory impairment in an older community. J Aging Health 22, 154-168.

[44] Schubert CR, Cruickshanks KJ, Fischer ME, Huang GH, Klein BE, Klein R, Pankow JS, Nondahl DM (2012) Olfactory impairment in an adult population: The Beaver Dam Offspring Study. Chem Senses 37, 325-334.

[45] Doty RL, Petersen I, Mensah N, Christensen K (2011) Genetic and environmental influences on odor identification ability in the very old. Psychol Aging 26, 864-871.

[46] Bramerson A, Johansson L, Ek L, Nordin S, Bende M (2004) Prevalence of olfactory dysfunction: The skovde population-based study. Laryngoscope 114, 733-737.

[47] Pinto JM, Schumm LP, Wroblewski KE, Kern DW, McClintock MK (2014) Racial disparities in olfactory loss among older adults in the United States. J Gerontol A Biol Sci Med Sci 69, 323-329.

[48] Landis BN, Konnerth CG, Hummel T (2004) A study on the frequency of olfactory dysfunction. Laryngoscope 114, 1764-1769. 
[49] Dong J, Pinto JM, Guo X, Alonso A, Tranah G, Cauley JA, Garcia M, Satterfield S, Huang X, Harris T, Mosley TH Jr, Chen H (2017) The prevalence of anosmia and associated factors among U.S. black and white older adults. J Gerontol A Biol Sci Med Sci 72, 1080-1086.

[50] Mullol J, Alobid I, Marino-Sanchez F, Quinto L, de Haro J, Bernal-Sprekelsen M, Valero A, Picado C, Marin C (2012) Furthering the understanding of olfaction, prevalence of loss of smell and risk factors: A population-based survey (OLFACAT study). BMJ Open 2, pii: e001256.

[51] Hoffman HJ, Rawal S, Li CM, Duffy VB (2016) New chemosensory component in the U.S. National Health and Nutrition Examination Survey (NHANES): First-year results for measured olfactory dysfunction. Rev Endocr Metab Disord 17, 221-240.

[52] Ajmani GS, Suh HH, Wroblewski KE, Pinto JM (2017) Smoking and olfactory dysfunction: A systematic literature review and meta-analysis. Laryngoscope 127, 1753-1761.

[53] Sharer JD, Leon-Sarmiento FE, Morley JF, Weintraub D, Doty RL (2015) Olfactory dysfunction in Parkinson's disease: Positive effect of cigarette smoking. Mov Disord 30, 859-862.

[54] Moccia M, Picillo M, Erro R, Vitale C, Amboni M, Palladino R, Cioffi DL, Barone P, Pellecchia MT (2014) How does smoking affect olfaction in Parkinson's disease? $J$ Neurol Sci 340, 215-217.

[55] Lucassen EB, Sterling NW, Lee EY, Chen H, Lewis MM, Kong L, Huang X (2014) History of smoking and olfaction in Parkinson's disease. Mov Disord 29, 1069-1074.

[56] Hernan MA, Hernandez-Diaz S, Robins JM (2004) A structural approach to selection bias. Epidemiology 15, 615-625.

[57] Postuma RB, Gagnon JF, Bertrand JA, Genier Marchand D, Montplaisir JY (2015) Parkinson risk in idiopathic REM sleep behavior disorder: Preparing for neuroprotective trials. Neurology 84, 1104-1113.

[58] Postuma RB, Gagnon JF, Vendette M, Fantini ML, Massicotte-Marquez J, Montplaisir J (2009) Quantifying the risk of neurodegenerative disease in idiopathic REM sleep behavior disorder. Neurology 72, 1296-1300.

[59] Claassen DO, Josephs KA, Ahlskog JE, Silber MH, Tippmann-Peikert M, Boeve BF (2010) REM sleep behavior disorder preceding other aspects of synucleinopathies by up to half a century. Neurology $\mathbf{7 5}$, 494-499.

[60] Stiasny-Kolster K, Mayer G, Schafer S, Moller JC, Heinzel-Gutenbrunner M, Oertel WH (2007) The REM sleep behavior disorder screening questionnaire-a new diagnostic instrument. Mov Disord 22, 2386-2393.

[61] Li SX, Wing YK, Lam SP, Zhang J, Yu MW, Ho CK, Tsoh J, Mok V (2009) Validation of a new REM sleep behavior disorder questionnaire (RBDQ-HK). Sleep Med 11, 43-48.

[62] Postuma RB, Arnulf I, Hogl B, Iranzo A, Miyamoto T, Dauvilliers Y, Oertel W, Ju YE, Puligheddu M, Jennum P, Pelletier A, Wolfson C, Leu-Semenescu S, Frauscher B, Miyamoto M, Cochen De Cock V, Unger MM, StiasnyKolster K, Fantini ML, Montplaisir JY (2012) A singlequestion screen for rapid eye movement sleep behavior disorder: A multicenter validation study. Mov Disord 27, 913-916.

[63] Boeve BF, Molano JR, Ferman TJ, Lin SC, Bieniek K, Tippmann-Peikert M, Boot B, St Louis EK, Knopman DS, Petersen RC, Silber MH (2013) Validation of the Mayo Sleep Questionnaire to screen for REM sleep behavior disorder in a community-based sample. J Clin Sleep Med 9, 475-480.

[64] Ma JF, Qiao Y, Gao X, Liang L, Liu XL, Li DH, Tang HD, Chen SD (2017) A community-based study of risk factors for probable rapid eye movement sleep behavior disorder. Sleep Med 30, 71-76.

[65] Boot BP, Boeve BF, Roberts RO, Ferman TJ, Geda YE, Pankratz VS, Ivnik RJ, Smith GE, McDade E, Christianson TJ, Knopman DS, Tangalos EG, Silber MH, Petersen RC (2012) Probable rapid eye movement sleep behavior disorder increases risk for mild cognitive impairment and Parkinson disease: A population-based study. Ann Neurol 71, 49-56.

[66] Mahlknecht P, Seppi K, Frauscher B, Kiechl S, Willeit J, Stockner H, Djamshidian A, Nocker M, Rastner V, Defrancesco M, Rungger G, Gasperi A, Poewe W, Hogl B (2015) Probable RBD and association with neurodegenerative disease markers: A population-based study. Mov Disord 30, 1417-1421.

[67] Wong JC, Li J, Pavlova M, Chen S, Wu A, Wu S, Gao X (2016) Risk factors for probable REM sleep behavior disorder: A community-based study. Neurology 86, 13061312.

[68] Boeve BF (2010) REM sleep behavior disorder: Updated review of the core features, the REM sleep behavior disorder-neurodegenerative disease association, evolving concepts, controversies, and future directions. Ann NY Acad Sci 1184, 15-54.

[69] Kang SH, Yoon IY, Lee SD, Han JW, Kim TH, Kim KW (2013) REM sleep behavior disorder in the Korean elderly population: Prevalence and clinical characteristics. Sleep 36, 1147-1152.

[70] Mahlknecht P, Iranzo A, Hogl B, Frauscher B, Muller C, Santamaria J, Tolosa E, Serradell M, Mitterling T, Gschliesser V, Goebel G, Brugger F, Scherfler C, Poewe W, Seppi K, Sleep Innsbruck Barcelona G (2015) Olfactory dysfunction predicts early transition to a Lewy body disease in idiopathic RBD. Neurology 84, 654-658.

[71] Ross GW, Abbott RD, Petrovitch H, Tanner CM, Davis DG, Nelson J, Markesbery WR, Hardman J, Masaki K, Launer L, White LR (2006) Association of olfactory dysfunction with incidental Lewy bodies. Mov Disord 21, 2062-2067.

[72] Driver-Dunckley E, Adler CH, Hentz JG, Dugger BN, Shill HA, Caviness JN, Sabbagh MN, Beach TG, Arizona Parkinson Disease C (2014) Olfactory dysfunction in incidental Lewy body disease and Parkinson's disease. Parkinsonism Relat Disord 20, 1260-1262.

[73] Jacobs ML, Dauvilliers Y, St Louis EK, McCarter SJ, Romenets SR, Pelletier A, Cherif M, Gagnon JF, Postuma RB (2016) Risk factor profile in Parkinson's disease subtype with REM sleep behavior disorder. J Parkinsons Dis 6, 231-237.

[74] Jafari S, Etminan M, Aminzadeh F, Samii A (2013) Head injury and risk of Parkinson disease: A systematic review and meta-analysis. Mov Disord 28, 1222-1229.

[75] Gao J, Liu R, Zhao E, Huang X, Nalls MA, Singleton $A B$, Chen $H$ (2015) Head injury, potential interaction with genes, and risk for Parkinson's disease. Parkinsonism Relat Disord 21, 292-296.

[76] Taylor KM, Saint-Hilaire MH, Sudarsky L, Simon DK, Hersh B, Sparrow D, Hu H, Weisskopf MG (2016) Head injury at early ages is associated with risk of Parkinson's disease. Parkinsonism Relat Disord 23, 57-61. 
[77] Gaenslen A, Wurster I, Brockmann K, Huber H, Godau J, Faust B, Lerche S, Eschweiler GW, Maetzler W, Berg D (2014) Prodromal features for Parkinson's diseasebaseline data from the TREND study. Eur J Neurol 21, 766-772.

[78] Baker JM, Hughes KC, Stephen CD, Schwarzschild MA, Ascherio A (2017) Motor and non-motor features of individuals with prodromal markers of Parkinson's disease. Mov Disord 32(9), e1-e19.

[79] Darweesh SK, Koudstaal PJ, Stricker BH, Hofman A, Steyerberg EW, Ikram MA (2016) Predicting Parkinson disease in the community using a nonmotor risk score. Eur J Epidemiol 31, 679-684.

[80] Ascherio A, Weisskopf MG, O'Reilly EJ, McCullough ML, Calle EE, Rodriguez C, Thun MJ (2004) Coffee consumption, gender, and Parkinson's disease mortality in the cancer prevention study II cohort: The modifying effects of estrogen. Am J Epidemiol 160, 977-984.

[81] Liu R, Guo X, Park Y, Huang X, Sinha R, Freedman ND, Hollenbeck AR, Blair A, Chen H (2012) Caffeine intake, smoking, and risk of Parkinson disease in men and women. Am J Epidemiol 175, 1200-1207.

[82] Benedetti MD, Bower JH, Maraganore DM, McDonnell SK, Peterson BJ, Ahlskog JE, Schaid DJ, Rocca WA (2000) Smoking, alcohol, and coffee consumption preceding Parkinson's disease: A case-control study. Neurology 55, 1350-1358.

[83] Palacios N, Gao X, McCullough ML, Schwarzschild MA, Shah R, Gapstur S, Ascherio A (2012) Caffeine and risk of Parkinson's disease in a large cohort of men and women. Mov Disord 27, 1276-1282.

[84] Tan LC, Koh W-P, Yuan J-M, Wang R, Au W-L, Tan JH, Tan E-K, Yu MC (2008) Differential effects of black versus green tea on risk of Parkinson's disease in the Singapore Chinese Health Study. Am J Epidemiol 167, 553-560.

[85] Chen H, Mosley TH, Alonso A, Huang X (2009) Plasma urate and Parkinson's disease in the Atherosclerosis Risk in Communities (ARIC) Study. Am J Epidemiol 169, 10641069.

[86] Gao X, O'Reilly EJ, Schwarzschild MA, Ascherio A (2016) Prospective study of plasma urate and risk of Parkinson disease in men and women. Neurology 86, 520526.

[87] Simon KC, Eberly S, Gao X, Oakes D, Tanner CM, Shoulson I, Fahn S, Schwarzschild MA, Ascherio A, Parkinson Study G (2014) Mendelian randomization of serum urate and parkinson disease progression. Ann Neurol 76, 862868.

[88] Huang X, Alonso A, Guo X, Umbach DM, Lichtenstein ML, Ballantyne CM, Mailman RB, Mosley TH, Chen H (2015) Statins, plasma cholesterol, and risk of Parkinson's disease: A prospective study. Mov Disord 30, 552-559.

[89] Huang X, Chen H, Miller WC, Mailman RB, Woodard JL, Chen PC, Xiang D, Murrow RW, Wang Y-Z, Poole $\mathrm{C}$ (2006) Lower low-density lipoprotein cholesterol levels are associated with Parkinson's disease. Mov Disord 22, 377-381.

[90] Gao X, Chen H, Schwarzschild MA, Ascherio A (2011) Use of ibuprofen and risk of Parkinson disease. Neurology 76, 863-869.

[91] Hancock DB, Martin ER, Stajich JM, Jewett R, Stacy MA, Scott BL, Vance JM, Scott WK (2007) Smoking, caffeine, and nonsteroidal anti-inflammatory drugs in families with Parkinson disease. Arch Neurol 64, 576-580.

[92] Chen H, Jacobs E, Schwarzschild MA, McCullough ML, Calle EE, Thun MJ, Ascherio A (2005) Nonsteroidal antiinflammatory drug use and the risk for Parkinson's disease. Ann Neurol 58, 963-967.

[93] Gao X, Simon KC, Schwarzschild MA, Ascherio A (2012) Prospective study of statin use and risk of Parkinson disease. Arch Neurol 69, 380-384.

[94] Liu G, Sterling NW, Kong L, Lewis MM, Mailman RB, Chen H, Leslie D, Huang X (2017) Statins may facilitate Parkinson's disease: Insight gained from a large, national claims database. Mov Disord 32, 913-917.

[95] Lee YC, Lin CH, Wu RM, Lin MS, Lin JW, Chang CH, Lai MS (2013) Discontinuation of statin therapy associates with Parkinson disease: A population-based study. Neurology 81, 410-416.

[96] Ritz B, Manthripragada AD, Qian L, Schernhammer E, Wermuth L, Olsen J, Friis S (2010) Statin use and Parkinson's disease in Denmark. Mov Disord 25, 1210-1216.

[97] Simon KC, Gao X, Chen H, Schwarzschild MA, Ascherio A (2010) Calcium channel blocker use and risk of Parkinson's disease. Mov Disord 25, 1818-1822.

[98] Ritz B, Rhodes SL, Qian L, Schernhammer E, Olsen JH, Friis S (2010) L-type calcium channel blockers and Parkinson disease in Denmark. Ann Neurol 67, 600-606.

[99] Tanner CM, Kamel F, Ross GW, Hoppin JA, Goldman SM, Korell M, Marras C, Bhudhikanok GS, Kasten M, Chade AR, Comyns K, Richards MB, Meng C, Priestley B, Fernandez HH, Cambi F, Umbach DM, Blair A, Sandler DP, Langston JW (2011) Rotenone, paraquat, and Parkinson's disease. Environ Health Perspect 119, 866-872.

[100] Costello S, Cockburn M, Bronstein J, Zhang X, Ritz B (2009) Parkinson's disease and residential exposure to maneb and paraquat from agricultural applications in the central valley of California. Am J Epidemiol 169, 919-926.

[101] Ascherio A, Chen H, Weisskopf MG, O'Reilly E, McCullough ML, Calle EE, Schwarzschild MA, Thun MJ (2006) Pesticide exposure and risk for Parkinson's disease. Ann Neurol 60, 197-203.

[102] Fang F, Chen H, Feldman AL, Kamel F, Ye W, Wirdefeldt K (2012) Head injury and Parkinson's disease: A population-based study. Mov Disord 27, 1632-1635.

[103] Gardner RC, Burke JF, Nettiksimmons J, Goldman S, Tanner CM, Yaffe K (2015) Traumatic brain injury in later life increases risk for Parkinson disease. Ann Neurol 77, 987-995.

[104] Chen H, O'Reilly E, McCullough ML, Rodriguez C, Schwarzschild MA, Calle EE, Thun MJ, Ascherio A (2007) Consumption of dairy products and risk of Parkinson's disease. Am J Epidemiol 165, 998-1006.

[105] Hughes KC, Gao X, Kim IY, Wang M, Weisskopf MG, Schwarzschild MA, Ascherio A (2017) Intake of dairy foods and risk of Parkinson disease. Neurology 89, 46-52.

[106] Chen H, Zhang SM, Hernan MA, Willett WC, Ascherio A (2002) Diet and Parkinson's disease: A potential role of dairy products in men. Ann Neurol 52, 793-801.

[107] Fereshtehnejad SM, Montplaisir JY, Pelletier A, Gagnon JF, Berg D, Postuma RB (2017) Validation of the MDS research criteria for prodromal Parkinson's disease: Longitudinal assessment in a REM sleep behavior disorder (RBD) cohort. Mov Disord 32, 865-873.

[108] Schenck CH, Hurwitz TD, Mahowald MW (1993) Symposium: Normal and abnormal REM sleep regulation: REM 
sleep behaviour disorder: An update on a series of 96 patients and a review of the world literature. J Sleep Res 2, 224-231.

[109] Olson EJ, Boeve BF, Silber MH (2000) Rapid eye movement sleep behaviour disorder: Demographic, clinical and laboratory findings in 93 cases. Brain 123, 331-339.

[110] Iranzo A, Molinuevo JL, Santamaria J, Serradell M, Marti MJ, Valldeoriola F, Tolosa E (2006) Rapid-eye-movement sleep behaviour disorder as an early marker for a neurodegenerative disorder: A descriptive study. Lancet Neurol 5, 572-577.

[111] Zhou J, Zhang J, Li Y, Du L, Li Z, Lei F, Wing YK, Kushida CA, Zhou D, Tang X (2015) Gender differences in REM sleep behavior disorder: A clinical and polysomnographic study in China. Sleep Med 16, 414-418.

[112] Frye RE, Schwartz BS, Doty RL (1990) Dose-related effects of cigarette smoking on olfactory function. JAMA 263, 1233-1236.

[113] Khil L, Wellmann J, Berger K (2015) Determinants of single and multiple sensory impairments in an urban population. Otolaryngol Head Neck Surg 153, 364-371.

[114] Rawal S, Hoffman HJ, Bainbridge KE, Huedo-Medina TB, Duffy VB (2016) Prevalence and Risk Factors of Self-Reported Smell and Taste Alterations: Results from the 2011-2012 US National Health and Nutrition Examination Survey (NHANES). Chem Senses 41, 69-76.
[115] Ranft U, Schikowski T, Sugiri D, Krutmann J, Kramer U (2009) Long-term exposure to traffic-related particulate matter impairs cognitive function in the elderly. Environ Res 109, 1004-1011.

[116] Siderowf A, Jennings D, Connolly J, Doty RL, Marek K, Stern MB (2007) Risk factors for Parkinson's disease and impaired olfaction in relatives of patients with Parkinson's disease. Mov Disord 22, 2249-2255.

[117] Liu HC, Wang SJ, Lin KP, Lin KN, Fuh JL, Teng EL (1995) Performance on a smell screening test (the MODSIT): A study of 510 predominantly illiterate Chinese subjects. Physiol Behav 58, 1251-1255.

[118] Gobba F, Abbacchini C (2012) Anosmia after exposure to a pyrethrin-based insecticide: A case report. Int J Occup Med Environ Health 25, 506-512.

[119] Quandt SA, Walker FO, Talton JW, Summers P, Chen H, McLeod DK, Arcury TA (2016) Olfactory function in Latino farmworkers: Subclinical neurological effects of pesticide exposure in a vulnerable population. $J$ Occup Environ Med 58, 248-253.

[120] Proskynitopoulos PJ, Stippler M, Kasper EM (2016) Posttraumatic anosmia in patients with mild traumatic brain injury (mTBI): A systematic and illustrated review. Surg Neurol Int 7, S263-S275. 